ment of neurochemistry, and this review is both admirable and timely. Ungar and Irwin undertake the herculean task of reviewing a vast literature on attempts to correlate gross neurochemical parameters with behaviour. This chapter contains a wealth of information and reference, but it is diffieult to do justice to such a diversity of topies in a single chapter. Aprison and Werman give a refreshingly modern account of strategy in the search for new central nervous system transmitters, emphasizing the necessity of an integrated biochemical, anatomical and physiological approach. This chapter is illustrated by reference to the authors' recent work concerning the possible role of glycine as an inhibitory transmitter in the spinal cord.

The next two chapters deal with neural mechanisms involved in the control of muscular activity. Bucy gives an excollent and concise historical perspective on this field, and illustrates the cxtreme complexity of the systems involved in motor control. Mettler gives an excellent and comprehensive review of these topies, many of which are of considerable clinical importance. In this chapter neuroanatomical and nourophysiological evidence is integrated in a masterly fashion. In other chapters Fischer and Rockey describe a novel approach to the psychophysies of excitation and tranquillization, Barbizet deals with theoretical aspects of learning processes and the hunt for the engram, and Gurdijan et al. describe the application of modern high-speed photographic and flash X-ray techniques to an experimental study of head injury.

Unlike most other serial publications, the volumes in the present series will not be devoted to single themes. To quote the editors: "By not having the chapters fit into any restrictive arrangement publication can be much more rapid than is the case with the usual multi-authored volume which covers one definite central theme". This is undoubtedly so, but is rapid publication more important than coherence? The present volume seemed to me to suffer greatly from the lack of a definite central theme, Although the individual chapters are in many cases excellent, they do not gain from publication as a collection covering miscellaneous topics. I would rather see such articles published in the appropriate review journals, or even as individual monographs in this series. Neurosciences research may require a multidisciplinary approach, but this is no justification for the publication of volumes such as this in which the individual contributions do not complement one another. Lesure L. Iversen

\section{PLANT TISSUE CULTURE}

\section{Plant Tissue Culture and Plant Morphogenesis}

By R. G. Butenko. Translated from the Russian. Pp. iv + 291. (Israel Program for Scientific Translations: Jerusalem. Distributed in the UK by H. A. Humphrey: London, October 1968.) 105s.

THF immediate reaction to this book is to welcome any account of the plant tissue culture work being carried out in the Soviet Union. The book is divided into two parts; the first part deals with tissue and cell culture techniques and the second part deals with the author's main interests in growth and morphogenesis. The latter section covers a wide range of topics including totipotency, nucleic acid and protein metabolism, secondary plant products, tumour tissues and pathology, organogenesis and the study of photoperiodic effects with isolated stem buds. In the foreword, there is a useful summary of the main interests of the plant tissue culture groups currently working in the communist countries.

Having welcomed this book, I have to admit to being disappointed with its contents. The original Russian version was published in 1964 and inevitakly some of the ideas seem rather dated in 1968. A far more serious fault, however, is the author's predilection for facile and sweeping statements which are either unsubstantiated or based on very limited experimental evidence. It would be tedious to list examples, which are frequent, but the statement that the increased respiration rate of a tissue explant "is due to three factors: trauma and availability of oxygen and carbohydrate" is typical.

On the whole, the translation has been efficient, but there are far too many typographical errors and the reproduction of the original photographs is very poor. The value of the book as a source of information is reduced by the absence of an index and the omission from the bibliography of some of the authors quoted in the text. The book is expensive and in view of its limitations it can hardly be recommended for general library purchase.

\section{G. G. Henshaw}

\section{TROPICAL SOILS}

\section{Introduction to the Study of Soils in Tropical and Sub-tropical Regions}

By P. Buringh. Pp. 118. (Centre for Agricultural Publishing and Documentation: Wageningen, 1968.) $12.50 \mathrm{Dfl}$.

A воок on tropical soils is a rare event. Apart from a chapter by Greene and one by Vine in textbooks of tropical agriculture there has been no general treatise on the subject in English since the outstanding work Tropical Soils by Mohr and van Baren. In this small volume Dr Buringh has included subtropical as well as tropical soils within his compass, and though it is an introduction he has written it for university students who have acquired "a basic knowledge of geology, mineralogy, soil chemistry, soil fertility, soil physies, soil biology and regional soil science". At this level one expects some study at depth, with a careful presentation of findings of research workers and a balanced assessment of their value. The treatment of the subject here, however, is oversimplified and superficial, with much repetition and over-obvious statementwhat the Dutch call "plain as a cow"--suggesting either ignorance by the writer, or ignorance implied by him in the reader, of the background subjects. There is seant reference to authorities and, where there is, there are serious omissions. Thus, in the list of early research workers, Pendleton, Greene and Milne are all left out, and Milne's catena concept is nowhere mentioned. The presentation is factual and systematic, yet many of the facts are disputable and the system open to objection. Thus much of what is said about ferallitic and fersiallitic soils is either too sweeping or inaccurate, and the classification of the soils, with its attempt to apply the rigid American. "seventh approximation" to the subject, seems particularly unsatisfactory when our knowledge of tropical soils is still so limited and bases for classification are still not agreed among the authorities. The overall impression of Buringh's work is that it is secondhand: even in dealing with soils which he should know well, he does not appear to have much personal acquaintance.

The work has been written directly in English and on the whole is easy to read, though the vocabulary is inadequate. There is a considerable sprinkling (often several to a page) of grammatical errors and misspellings, some rather serious. The colour photographs, as is usual, give a somewhat distorted impression of soil colours, and the wrong orientation of one of the black-and-white photographs and the wrong positioning of the captions of two others (mentioned on the errata slip) are symptomatic not only of the inadequacy of photographs generally to represent soil features, but also of the carelessness in the production of this particular work. The price, at about 30 shillings, is high.
G. A. Worralt. 